\title{
The Influence of Recruitment Process on Performance and Job Satisfaction at The Dharmawangsa Jakarta
}

\author{
Amirah Fathin $^{1 *}$, Lestari Ningrum² ${ }^{2}$ Ahmad Junaedi Abas ${ }^{3}$ \\ Sekolah Tinggi Pariwisata Trisakti \\ *amirahfathin75@gmail.com
}

\begin{abstract}
This study examines the influence of the recruitment process on performance and job satisfaction at The Dharmawangsa Jakarta. Recruitment process is an independent variable, while performance and job satisfaction are dependent variables. This study is explanatory research with descriptive correlation methods. The number of sample is 101 respondents. The purposive sampling technique is applied with criteria of The Dharmawangsa Jakarta. Data are collected with questionnaires and processed with data analysis. These results indicate that the reliability test was very high $(0.880)$ and from 34 instruments statements only 1 was invalid. It showed that 101 new employees as respondents consistently answered because they understood and experienced. Each variable has a mean value of 4.11 for the recruitment process that is important for new employees, 4.16 for performance that is well, and 3.79 for job satisfaction that is new employees are satisfied. The recruitment process has a low correlation of 0.329 with performance and 0.268 with job satisfaction. The recruitment process also has a little effect of $0.8 \%$ on performance and $7.2 \%$ on job satisfaction. Based on these results, The Dharmawagsa Jakarta should improve the recruitment procedure, increase a conducive, and comfortable working atmosphere.
\end{abstract}

Keywords: Recruitment Process, Performance, and Job Satisfaction. 
The Influence of Recruitment Process on Performance and

Job Satisfaction at The Dharmawangsa Jakarta

\section{A. Introduction}

In the current era of globalization, economic development is the goal of every country in the world, including of Indonesia. Economic development is a process that is carried out continuously in order to create changes the social, political, and economic itself.

The problem faced by Indonesia in the process of economic development is the existence of natural resources is abundant with low quality of Human Resources (HR), as well as with limited capital. This is reinforced by the increasingly high population growth which is indicated by higher birth rates compared to the mortality rate.

Based on data submitted by the Minister of Home Affairs RI Tjahjo Kumolo (cited in Setiawan, 2017), the number of Indonesian population as of June, 302016 was 257,912,349 inhabitants. Thus, given the increasing number of people causing excessive labor supply, the demand for labor is very limited.

Most working people have a desire to work in the formal sector. Therefore, many companies stood in Jakarta. One of which the hospitality company is The Dharmawangsa Jakarta located in Kebayoran Baru, South Jakarta. Hariyadi Sukamdani as Chairman of Indonesian Hotel and Restaurant Association (PHRI) stated that in 2016 the number of hotel rooms in Indonesia reaches 270,500 units and in 2017 increases 58,000 units. In addition, property consultant Colliers International Indonesia, Eka (2016) stated that 39 new hotels to be built in Jakarta consist of 9 budget hotels, 10 three star hotels, 15 four star hotels and 5 five star hotels ahead of the 2018 Asian Games.

The growing business of hospitality services, of course, increasingly require employees with good performance, reliable, honest, skillful, and have a good hospitality competence in able to meet the wishes of guests with all their needs in able to always return to the hotel.

In addition to the creation of good work performance, the main purpose of work is to achieve job satisfaction for its employees. So, the employees can work with joy in accordance with applicable procedures, able to compete and excel in the field, also able to provide innovation in work.

Finding, recruiting, and selecting employees with the required performance not an easy task, because the existence of a good recruitment process hired qualified employees who can lift the image of the company. And create a dynamic work environment and professional. Therefore, it takes good cooperation from each department in realizing the procurement of new employees.

The purpose of this research is to find out the implementation of the recruitment process, performance, job satisfaction, the influence of recruitment process toward performance, and the influence of recruitment process toward job satisfaction of new employees at The Dharmawangsa Jakarta.

TRJ Tourism Research Journal, Volume 1 (1), 2018 
The Influence of Recruitment Process on Performance and

Job Satisfaction at The Dharmawangsa Jakarta

\section{B. Literature Review}

\section{Recruitment Process}

Recruitment is as a process to get the candidate employees who have the ability in accordance with the qualifications and needs of an organization/company (Mardianto (2014: 8). In determining and implementing appropriate and effective recruitment procedures, a hotel can survive in the face of a dynamic environment by acquiring employees who have the ability of reliable, professional, and able to build the image of the company in accordance with the purpose of the hotel, so as to create a hospitality business into the trust of the guests.

The main purpose of the recruitment process is to get the right person for a particular position, so that the person is able to work optimally and can stay in the company for a long time.

There are several processes of recruitment and selection according to Yuli (in Nurhayati, 2016), consist of:

a. Planning and Forecasting

Phase Planning and job forecasting activities are core activities that always underlie other activities, including what type of work will be filled out. This stage will be developed again in the next stages.

b. Identification

The next stage is to determine the "who" candidate to be recruited. Who is here about what capabilities the candidate has and what skills and experience they have had.

c. Applicants Complete Application Form

Identification of candidates can be done by asking the candidates to enter the application file that was announced in advertising. Applicants who are accepted administratively are candidates who meet the requirements set by the organization. Noteworthy in this stage is the suitability between the contents of the application sent with a filled form.

d. General Intelligence Test

This test is commonly known as the IQ test and is actually a mixed talent test. This test can be used to provide a common standard measure where different educational skills can be seen.

e. Skills Tests

This test is a test of ability or knowledge. This test measures the skills achieved in a particular field or skill. For example typing tests, someone who can type quickly can be declared already experienced.

f. Talent Test

This test is a person's ability to do a job. This test includes the ability to associate with numbers, letters or writing and machines. For example computer programming test.

TRJ Tourism Research Journal, Volume 1 (1), 2018 
The Influence of Recruitment Process on Performance and

Job Satisfaction at The Dharmawangsa Jakarta

g. Personality test

This test reveals the potential capabilities of real prospective workers, and can be known talent, interest, motivation, emotion, personality and other special abilities that exist in prospective workers.

h. Medical check up

This test covers the physician's physical examination whether it meets the specifications that have been required to take office, such as hearing, sight, (color blindness or not) and having a disability or not.

i. Interview

This interview is conducted to determine the extent to which the applicant's practical ability to do and get an idea of whether the applicant can be invited to work together or not.

j. Determining Accepted or Rejected

Top managers will decide on the acceptance or rejection of applicants upon receipt of the results of previous selection. Applicants who do not meet the specifications are rejected, whereas applicants who graduate from each selection are decided to be accepted as prospective employees on probation.

\section{Performance}

Job satisfaction is interesting and important. The most fundamental is the influence of job satisfaction on the organization that will affect employee performance (Mathis, et al., 2001).

Beside of that, performance is essentially what employees do. The performance of an employee will be good, if employees have high expertise, willingness to work, the rewards/wages are feasible and have hope for the future. Optimal performance will be realized when the organization can select employees who have the motivation and skills appropriate to their work and choose conditions that enable them to work optimally.

Performance is an activity of human resource management to achieve corporate objectives, as individual responsibilities to the work, and help define performance expectations. Performance goals are adjusting individual performance expectations to organizational goals. The conformity between achieving this goal and the goals of the organization will be able to achieve good performance (Wibowo, 2016).

According to Umar (cited in Mangkunegara, 2006) and Agustiningrum, et al. (2012) performance measures include:

a. Quality of Work

Quality must be produced whether or not involves the calculation of the output and the implementation process of the activities of the employees, especially in relation to the output.

b. Employee Honesty

TRJ Tourism Research Journal, Volume 1 (1), 2018 
The Influence of Recruitment Process on Performance and Job Satisfaction at The Dharmawangsa Jakarta

It is the sincerity of an employee in performing his duties and is capable of not abusing any given authority.

c. Initiative

The ability to act is independent of others and able to develop a range of activities and can discover new or innovative ways.

d. Attendance

Obligation to be performed by the employees in any job where attendance is the main thing that every employees should undertake.

e. Attitude

A willingness to react in the face of a certain situation or situation normally.

f. Reliability

Total of all skills needed to achieve reliable results.

g. Cooperation

The ability of an employee to work together with others in completing a specified task, so as to achieve utility and maximum results. The willingness of employees to participate and work with other employees vertically and horizontally in and out of work so that the work will increase.

h. Knowledge of Work

Knowledge possessed by every employee in performing a job so that it can run effectively and efficiently.

i. Responsible

The ability of an employee to complete the work that is bestowed on him as well as possible.

j. Punctuality

Timekeeping measurement is a special type of quantitative measurement to determine the timeliness of completion of an activity.

\section{Job Satisfaction}

Job satisfaction is a pleasant emotional attitude and love his job (Hasibuan, 2013: 202). This attitude is reflected by work morale, discipline, and work performance. Luthans in Novita, et al (2016) revealed that there are a number of job satisfaction indicators:

a. The work itself

Job satisfaction is itself a major source of satisfaction.

b. Salary

Wages and salaries are known to be significant, but complex in a cognitive and multidimensional factor in job satisfaction.

c. Promotion

Promotional opportunities seem to have a different effect on job satisfaction because the promotion has a number of different forms and has numerous rewards.

TRJ Tourism Research Journal, Volume 1 (1), 2018 
The Influence of Recruitment Process on Performance and

Job Satisfaction at The Dharmawangsa Jakarta

d. Supervision

Supervision is another important source of job satisfaction. There are two dimensions of supervisory style that affect job satisfaction. The first is centered on employees and the other dimension is participation or influence, as illustrated by managers who allow people to participate in decision-making.

e. Co-workers

Co-workers or team members who are cooperative are the simplest source of job satisfaction in individual employees. Working groups, especially strong teams, act as a source of support, comfort, advice, and assistance to individual members.

f. Working Conditions

Work environment effects on job satisfaction, as well as work group effects. If things go well, there's no job satisfaction problem.

\section{Relationship between Variables}

The hypothesis is the third step in research after putting forward the frame of mind and the foundation of the theory (Sugiyono, 2013: 96). The hypothesis is a temporary answer to the problem under study. The suspended hypothesis is tested to show true or false freely.

Hypothesis 1

$\mathrm{HO}$ : There is no positive relationship between the recruitment process with performance

H1 : There is a positive relationship between the recruitment process with performance.

Hypothesis 2

$\mathrm{HO}$ : There is no positive relationship between the recruitment process on employee satisfaction.

H1 : There is a positive relationship between the recruitment process on employee satisfaction. 
The Influence of Recruitment Process on Performance and

Job Satisfaction at The Dharmawangsa Jakarta

\section{Conceptual Framework}

Figure 1: Conceptual Framework

\section{Recruitment Process (X) \\ 1. Complete The Form \\ 2. Personality Test \\ 3. Interview \\ 4. Determine Accept or Reject \\ 5. Medical Check Up}

Source: Yuli (2005: 50)

in Nurhayati (2016)

\section{Performance (Y1)}

1. Quality of Work

2. Honesty of Employee

3. Initiative

4. Attendance

5. Teamwork

6. Knowledge of Work
Source: Umar (1997) in

Mangkunegara (2006) in

Agustiningrum (2012)

\section{Job Satisfaction (Y2)}

1. Job Itself

2. Salary

3. Promotion

4. Supervision

5. Co-workers

6. Working Condition

Source: Luthans (2006: 244-245) in Novita (2016)

\section{Research Methodology}

This type of research used in this research is explanatory research with descriptive and correlation method. From the explanation in this study the variables that will be used, among others:

1. Recruitment process $(\mathrm{X})$

2. Performance (Y1)

3. Job satisfaction (Y2)

In this research the population is employees at all departments consist of 338 people. Sampling used in this research is purposive sampling. Determination of the number of samples in this refers to opinion of Sugiyono (2013: 116), the sample is part of the number and characteristics possessed by that population. Sample measurement is a step to determine the size of samples taken in conducting the research of an object.

In this research the structure and method of data analysis to be used are: 
The Influence of Recruitment Process on Performance and

Job Satisfaction at The Dharmawangsa Jakarta

\section{Reliability Test}

Reliability is an indicator of reliability or reliability of a measurement result (Morrisan, 2014: 99). A measurement is called reliable or has reliability if it consistently gives the same answer. This test is used to find out how far the measurement results remain consistent when measured twice or more against the same symptoms using the same gauge.

\section{Validity Test}

In addition to be reliable, a measurement must also have validity. Validity refers to how far an empirical measure adequately describes the true meaning of the concept under study. In other words, a valid measurement instrument measures what should be measured, or measures what we want to measure.

\section{Descriptive Statistic Test}

According to Aziz (2017) to assess the variables $x$ and y variables, then the analysis used is based on the mean (mean) of each variable. This average value is obtained by summing the overall data in each variable then divided by the number of respondents.

\section{Coefficient Correlation Test}

The correlation coefficient is a statistical tool, which can be used to compare the results of measurements of two different variables in order to determine the degree of relationship between these variable (Arikunto, 2013: 313).

\section{Regression Test}

Sugiyono (2013: 277) defines that multiple regression analysis is used to predict how the dependent variable (rise and fall) state, when two or more independent variables as a predictor factor are manipulated (up and down).

\section{Result}

The questionnaires had been distributed to respondents with 101 questionnaires. On the process of calculating the data, there are 34 instrument questions. Results of tests in this research are:

1. Reliability Test

Table 1. Case Processing Summary

\begin{tabular}{|c|r|r|}
\hline & \multicolumn{1}{|c|}{ N } & \multicolumn{1}{c|}{} \\
\hline Cases Valid & 101 & 100.0 \\
Excluded $^{\mathrm{a}}$ & 0 & .0 \\
Total & 101 & 100.0 \\
\hline
\end{tabular}

Table 2. Reliability Statistics

\begin{tabular}{|r|r|}
\hline Cronbach's Alpha & N of Items \\
\hline .880 & 34 \\
\hline
\end{tabular}

rism Research Journal, Volume 1 (1), 2018 
The Influence of Recruitment Process on Performance and Job Satisfaction at The Dharmawangsa Jakarta

The result of SPSS program processing for rebility test shows that respondents who successfully answered 34 statements are 101 respondents, and the 101 respondents answered with a very high reliability: 0.880. (Arikunto, 2013: 122), of which 34 statements are answered consistently by the respondents.

\section{Validity Test}

Table 3. Item-Total Statistics

\begin{tabular}{|c|c|c|c|c|}
\hline & $\begin{array}{l}\text { Scale Mean if } \\
\text { Item Deleted }\end{array}$ & $\begin{array}{c}\text { Scale Variance if } \\
\text { Item Deleted }\end{array}$ & $\begin{array}{l}\text { Corrected Item- } \\
\text { Total Correlation }\end{array}$ & $\begin{array}{c}\text { Cronbach's Alpha if } \\
\text { Item Deleted }\end{array}$ \\
\hline Complete The Form 1 & 132.97 & 80.109 & .261 & .879 \\
\hline Complete The Form 2 & 132.92 & 79.814 & .331 & .878 \\
\hline Personality Test 1 & 133.12 & 79.046 & .290 & .879 \\
\hline Personality Test 2 & 132.82 & 78.728 & .374 & .877 \\
\hline Interview1 & 132.64 & 77.612 & .488 & .875 \\
\hline Interview2 & 132.71 & 79.207 & .346 & .878 \\
\hline Determine Accept/ Reject 1 & 132.74 & 78.693 & .361 & .877 \\
\hline Determine Accept/ Reject 2 & 132.65 & 79.929 & .275 & .879 \\
\hline Medical Check Up1 & 132.50 & 78.772 & .296 & .879 \\
\hline Medical Check Up2 & 132.34 & 80.086 & .277 & .879 \\
\hline Quality of Work 1 & 132.71 & 78.867 & .446 & .876 \\
\hline Quality of Work 2 & 132.81 & 77.774 & .509 & .875 \\
\hline Honesty of Employee1 & 132.76 & 77.103 & .523 & .874 \\
\hline Honesty of Employee 2 & 132.66 & 78.626 & .442 & .876 \\
\hline Initiative 1 & 132.82 & 79.388 & .223 & .881 \\
\hline Initiative 2 & 132.62 & 78.377 & .405 & .876 \\
\hline Attendance 1 & 132.58 & 81.025 & .168 & .881 \\
\hline Attendance 2 & 132.57 & 81.367 & .146 & .881 \\
\hline Teamwork 1 & 132.60 & 78.962 & .412 & .876 \\
\hline Teamwork 2 & 132.65 & 78.189 & .505 & .875 \\
\hline Knowledge of Work 1 & 132.69 & 78.675 & .499 & .875 \\
\hline Knowledge of Work 2 & 132.69 & 78.455 & .526 & .875 \\
\hline Work Itself 1 & 132.79 & 77.366 & .535 & .874 \\
\hline Work Itself 2 & 132.79 & 77.066 & .566 & .873 \\
\hline Salary 1 & 133.13 & 79.773 & .265 & .879 \\
\hline Salary 2 & 133.45 & 77.770 & .349 & .878 \\
\hline
\end{tabular}

TRJ Tourism Research Journal, Volume 1 (1), 2018 
The Influence of Recruitment Process on Performance and

Job Satisfaction at The Dharmawangsa Jakarta

\begin{tabular}{l|l|l|l|l} 
Promotion 1 & 133.04 & 74.378 & .651 & .870 \\
Promotion 2 & 132.96 & 76.438 & .555 & .873 \\
Supervision 1 & 133.01 & 78.030 & .500 & .875 \\
Supervision 2 & 133.06 & 76.916 & .518 & .874 \\
Co-Workers 1 & 133.09 & 78.562 & .367 & .877 \\
Co-Workers 2 & 133.08 & 77.414 & .463 & .875 \\
Working Condition 1 & 133.23 & 79.058 & .345 & .878 \\
Working Condition 2 & 133.19 & 78.494 & .394 & .877 \\
\hline
\end{tabular}

The result of SPSS program processing for validity test, obtained df 99, t_table 1.66, and r_tabel 0.16 , then in table 4.3 it appears that the result of t_hitung (Corrected Item-Total Correlation) in the presence statement 2 is smaller than r_tabel, so the value of the statement can not be used for subsequent calculations.

3. Descriptive Statistic Test

Table 4. Mean Value of Recruitment Process and Performance

\begin{tabular}{llrrr}
\hline \multicolumn{4}{c}{ Statistics } & \\
N & Valid & Recruitment Process & Performance & \\
& Missing & 101 & 101 \\
Mean & & 0 & 0 \\
\hline
\end{tabular}

The result of SPSS program processing on the mean/average value of the recruitment process and employee performance resulted that the recruitment process has an average value of 4.11 means the recruitment process is considered important in the implementation of employee performance. And employee performance has an average value of 4.16 means the employee's performance is considered good based on the recruitment process that has been implemented.

Table 5. Mean Value of Recruitment Process and Job Satisfaction

\begin{tabular}{llrr} 
& & Recruitment Process & Job Satisfaction \\
N & Valid & 101 & 101 \\
& Missing & 0 & 0 \\
Mean & & 4.1198 & 3.7937 \\
\hline
\end{tabular}

The results of SPSS program processing on the mean / average value of the recruitment process and job satisfaction results obtained that the recruitment 
The Influence of Recruitment Process on Performance and

Job Satisfaction at The Dharmawangsa Jakarta

process has an average value of 4.11 means the recruitment process is considered important for employee job satisfaction. And job satisfaction has an average value of 3.79, means job satisfaction assessed satisfied on the implementation of recruitment process in The Dharmawangsa Jakarta.

4. Coefficient Correlation Test

Table 6. Coefficient Correlation between Recruitment Process and Performance

Correlations

\begin{tabular}{llrr} 
& & Recruitment Process & Performance \\
\multirow{2}{*}{ Recruitment Process } & Pearson Correlation & 1 & $.329^{* *}$ \\
& Sig. (2-tailed) & 101 & .001 \\
\multirow{3}{*}{ Performance } & N & $.329^{* *}$ & 101 \\
& Pearson Correlation & .001 & 1 \\
& Sig. (2-tailed) & 101 & 101 \\
\hline
\end{tabular}

The result of SPSS program processing on correlation coefficient test of recruitment process with employee performance is 0.329 , so the recruitment process has low relation to employee performance in The Dharmawangsa Jakarta. While the significant value of 0.01 , smaller than 0.05 , means $\mathrm{H} 1$ is accepted, that is the relationship between the recruitment process and employee performance.

\begin{tabular}{|c|c|c|c|}
\hline & Corre & ons & \\
\hline & & Recruitment Process & Job Satisfaction \\
\hline Recruitment Process & Pearson Correlation & 1 & $.268^{* *}$ \\
\hline & Sig. (2-tailed) & & .007 \\
\hline & $\mathrm{N}$ & 101 & 101 \\
\hline Job Satisfaction & Pearson Correlation & $.268^{* *}$ & 1 \\
\hline & Sig. (2-tailed) & .007 & \\
\hline & $\mathrm{N}$ & 101 & 101 \\
\hline
\end{tabular}

The results of SPSS program processing on correlation coefficient test recruitment process with job satisfaction is 0.268 , so recruitment process has a low relationship to employee job satisfaction in The Dharmawangsa Jakarta, while significant value 0.07 greater than 0.05 . If the significant value greater than 0.05 , means Ho accepted, ie there is no positive relationship between the recruitment process and job satisfaction.

TRJ Tourism Research Journal, Volume 1 (1), 2018 
The Influence of Recruitment Process on Performance and

Job Satisfaction at The Dharmawangsa Jakarta

5. Regression Test

\begin{tabular}{ccrrr} 
Table 8. The Influence of Recruitment Process on Performance \\
\hline \multicolumn{5}{c}{ Model Summary } \\
Model & $\mathrm{R}$ & R Square & Adjusted R Square & Std. Error of the Estimate \\
1 & $.329^{\mathrm{a}}$ & .108 & .099 & .32614 \\
\hline
\end{tabular}

The result of regression between recruitment process and employee performance get value $10,8 \%$, which means recruitment process in The Dharmawangsa Jakarta only influence $10.8 \%$ to employee performance, $89,2 \%$ The rest of new employee performance in The Dharmawangsa Jakarta influenced by variable beside process recruitment.

\begin{tabular}{|c|c|c|c|c|c|c|}
\hline & & Table 9. C & Defficients & & & \\
\hline & & Unstandardize & Coefficients & $\begin{array}{l}\text { Standardized } \\
\text { Coefficients }\end{array}$ & & \\
\hline Model & & B & Std. Error & Beta & $\mathrm{T}$ & \\
\hline 1 & (Cons & 2.822 & .390 & & 7.238 & .000 \\
\hline & Recruitment Process & .327 & .094 & .329 & 3.465 & .001 \\
\hline
\end{tabular}

Table 4.18 illustrates the regression equation. $\mathrm{Y}=2.822+0.327 \mathrm{X}$.

$\mathrm{Y}=$ Performance, $\mathrm{X}=$ Recruitment process

The result of regression coefficient of 0.327 states that there is addition to the recruitment process will increase the employee performance value. Because the overall number is positive, it states that the relationship of the two variables is positive direction, where employee performance is formed due to the recruitment process done, but only affects by $10.8 \%$ only.

\section{Table 10. The Influence of Recruitment Process on Job Satisfaction Model Summary \\ Model R R Square Adjusted R Square Std. Error of the Estimate

\begin{tabular}{lllll}
1 & $.268^{\mathrm{a}}$ & .072 & .063 & .39502 \\
\hline
\end{tabular}

Regression result between recruitment process and job satisfaction get value $7.2 \%$, which means recruitment process in The Dharmawangsa Jakarta influenced only $7.2 \%$ on job satisfaction, $92.8 \%$ The rest of the new employee job satisfaction in The Dharmawangsa Jakarta is influenced by variables other than recruitment process.

\begin{tabular}{|c|c|c|c|c|c|c|}
\hline \multicolumn{7}{|c|}{ Table 11. Coefficients ${ }^{a}$} \\
\hline \multirow{4}{*}{1} & & Unstandardized & Coefficients & $\begin{array}{l}\text { Standardized } \\
\text { Coefficients }\end{array}$ & & \\
\hline & Model & B & Std. Error & Beta & $\mathrm{T}$ & Sig. \\
\hline & (Constant) & 2.489 & .472 & & 5.271 & .000 \\
\hline & ProsesRekrutmen & .317 & .114 & .268 & 2.772 & .007 \\
\hline
\end{tabular}

TRJ Tourism Research Journal, Volume 1 (1), 2018 
The Influence of Recruitment Process on Performance and

Job Satisfaction at The Dharmawangsa Jakarta

Table 4-20 illustrates the regression equation. $\mathrm{Y}=2.489+0.317 \mathrm{X} . \mathrm{Y}=\mathrm{Job}$ satisfaction, $\mathrm{X}=$ Recruitment process

The result of regression coefficient of 0.317 states that there is addition to the recruitment process will increase the value of job satisfaction. Because the overall number is positive, it states that the relationship of two variables is positive direction, where job satisfaction is formed due to the recruitment process done, but only affects by $7.2 \%$ only.

\section{E. Conclusion}

Based on the description in the preceding chapter, especially in analysis, the following conclusion can be drawn:

1. Recruitment process got score 4.11, it means important by new employees at The Dharmawangsa Jakarta

2. Performance got score 4.16, it means good by new employees at The Dharmawangsa Jakarta by new employees at The Dharmawangsa Jakarta

3. Job satisfaction got score 3.79, it means new employees feel satisfied

4. Correlation between recruitment process and performance is low (0.329), and the effect of recruitment process on new employees' performance is little $(10.8 \%)$

5. Correlation between recruitment process and job satisfaction is low (0.268), and the effect of recruitment process on new employees' job satisfaction is little $(7.2 \%)$

Here are suggestions that can be realized by the destination and further research:

1. A department that requires new employee candidates should clearly inform, informative, and prepared job descriptions so that the recruitment process works well and smoothly.

2. If there is a change of organizational structure in a department, then it is necessary first notification to HRD to be able to determine the required candidate in accordance with the position in the department.

3. Interviews have a value of 4.18. However, clear information about working standards in The Dharmawangsa Jakarta is still needed and the tasks and responsibilities that must be done. So that when they become new employees, they will not experience the mistake of information obtained when the recruitment process with reality in the intended department.

4. Personality test has the smallest value compared with other recruitment process indicator is 3.89. The HRD should inform the applicant about the results of the personality test. So the applicants can know their own expertise, their potential, and their attitude in dealing with problems.

5. Determine accept/rejected has a value of 4.16. So HRD should quickly inform to the applicants who have followed the stages of the recruitment

TRJ Tourism Research Journal, Volume 1 (1), 2018 
The Influence of Recruitment Process on Performance and Job Satisfaction at The Dharmawangsa Jakarta

process. So they do not have to wait long to know the results of the recruitment process.

6. Quality of work has the smallest value compared to other employee performance aspects is 4.09. Thus, it is necessary to improve the quality of work for each employee to be able to always satisfy customers with joy.

7. The initiative has a value of 4.13. Thus, it is necessary to increase the initiative for every employee to be able to continue to create more innovative products and services so as to always attract customers.

8. Salary has the smallest value compared to other aspects of job satisfaction is 3.57. Wages/salaries should be given in accordance with the level of complexity and responsibility undertaken. In particular, the HRD provides clear and detailed information on the reasons for providing the wages with the responsibilities given. Thus, new employees will be satisfied with the given wage.

9. Supervision has a value of 3.82. It takes active participation and more support by each boss towards new employees, so they can be more confident in developing products and services.

10. Working condition has a value of 3.65. Although in the face of a fairly tight business competition, the hotel boss should provide conducive work environment, warm, calm, and comfortable. So that new employees can work wholeheartedly without any pressure.

\section{F. Acknowledgement}

I would express my sincere appreciation to my final project advisor Lestari Ningrum, M.H., M.Si.Par. and my examiner Ahmad Junaedi Abas, M.M. for the supporting critics, building motivations and life lesson that have guided the researcher.

Depp appreciation will also not forgotten to Diploma 4 Hospitality Management Trisakti Institute of Tourism for giving me a scholarship "Beasiswa Unggulan", and all of staffs in Diploma 4 Hospitality Management for providing helps and always make sure I feel comfortable during my study here. Thank you for granting me for such rare opportunity.

\section{REFERENCES}

Agustiningrum, A., Indrawati, C.D.S., Rahmanto, A.N. (2012). Gaya Kepemimpinan dan Motivasi Kerja Terhadap Kinerja Pegawai. Jurnal Pendidikan Administrasi Perkantoran, 1(1).

Arikunto S. (2013). Prosedur Penelitian: Suatu Pendekatan Praktik. Jakarta: Rineka Cipta.

TRJ Tourism Research Journal, Volume 1 (1), 2018 
The Influence of Recruitment Process on Performance and Job Satisfaction at The Dharmawangsa Jakarta

Aziz, T.A., Ma'rif, M.S., Sukmawati, A. (2017). Pengaruh Rekrutmen dan Seleksi Terhadap Kinerja. Jurnal Aplikasi Bisnis dan Manajemen, 3(2). ISSN 25285149.

Eka. (2016), Sebanyak 39 Hotel Baru Dibangun di Jakarta Jelang Asian Games 2018. Jktproperty.com. Retrieved from http://iktproperty.com/sebanyak39-hotel-baru-dibangun-di-jakarta-jelang-asian-games-2018/

Hasibuan, M.S.P. (2013). Manajemen Sumber Daya manusia. Jakarta: PT. Bumi Aksara.

Mangkunegara, A.A.A.P. (2006). Perencanaan dan Pengembangan Manajemen Sumber Daya Manusia. Jakarta: Refika Aditama.

Mardianto, A. (2014). Optimizing Recruitment Strategy: Recruitment Management. Jakarta: Pinasthika

Mathis, R.L. \& Jackson, J.H. (2001). Manajemen Sumber Daya Manusia.Terjemahan. Jakarta: Salemba Empat. - (2006). Manajemen Sumber Daya Manusia.Terjemahan Dian Angelia. Jakarta: Salemba Empat.

Morissan. (2014). Teori Komunikasi: Individu Hingga Massa. Jakarta: Kencana

Novita, Sunuharjo, B.S. \& Ruhana, I. (2016). Pengaruh Kepuasan Kerja dan Komitmen Organisasional Terhadap Kinerja Karyawan (Studi Pada PT. Telekomunikasi Indonesia, TBK Witel Jatim Selatan, Malang). Jurnal Administrasi Bisnis, 34(1), 39-40.

Nurhayati, T. (2016). Pengaruh Rekrutmen Terhadap Kinerja Karyawan (Studi Kasus Pada Hotel Bintang Lima Pekanbaru). Jurnal Online Mabasiswa Fakultas Ilmu Sosial dan Ilmu Politik, 3(1), 4-5.

Setiawan, D. (2017). Data Terkini, Jumlah Penduduk Indonesia Lebih dari 262 Juta Jiwa. Koran Tribun Jateng. Retrieved from http://jateng.tribunnews.com/2017/08/02/data-terkini-jumlahpenduduk-indonesia-lebih-dari-262-juta-jiwa

Sugiyono. (2013). Metode Penelitian Kuantitatif, Kualitatif, dan R\&D. Bandung: Alfabeta.

(2014). Metode Penelitian Kuantitatif, Kualitatif, dan Kombinasi Mixed methods). Bandung: Alfabeta.

TRJ Tourism Research Journal, Volume 1 (1), 2018 
The Influence of Recruitment Process on Performance and Job Satisfaction at The Dharmawangsa Jakarta . (2017). Metode Penelitian Kuantitatif, Kualitatif, dan R\&D. Bandung: Alfabeta.

Wibowo. (2016). Manajemen Kinerja (Edisi kelima). Jakarta: Raja Grafindo Persada.

TRJ Tourism Research Journal, Volume 1 (1), 2018 